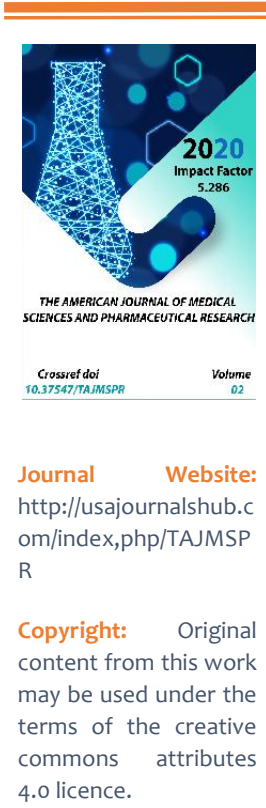

\title{
Disturbance Of The Hormonal Background In Women With Hypofunction Of The Ovaries With Menier's Disease
}

\author{
Makhzuna Nasretdinova \\ Doctor Of Medical Sciences Associate Professor Of The Department Of Otorhinolaryngology \\ Of The Samarkand State Medical Institute, Uzbekistan \\ Ozod Nabiev \\ Samarkand State Medical Institute, Republic Of Uzbekistan, Samarkand, Uzbekistan
}

\section{ABSTRACT}

Meniere's disease is a non-purulent disease of the inner ear, characterized by an increase in the volume of endolymph. In addition, it is known that the onset of the disease in women often coincides with periods of physiological or pathological decrease in the hormonal function of the ovaries: the hemorrhagic phase of the menstrual cycle, menstrual irregularities accompanied by hypoestrogenia. We studied 18 people, conducted audiometric, vestibulometric and electronhistagographic studies. Patients were treated during the period of remission for 2-3 menstrual cycles in continuous monitoring in the form of dynamic hormonal studies excretion of sex steroids. Based on the results of hormonal examination and treatment, it should be assumed that hormonal therapy for women with Meniere's disease, which occurs against the background of ovarian hypofunction, is quite effective for stopping attacks of vestibular disorders. This therapy is a substitute.

\section{KEYWORDS}

Meniere, estrogens, progesterol, corticosteroids, nystagmus, hydrops.

\section{INTRODUCTION}

The development of pathogenetic therapy for Meniere's disease presents significant difficulties, since the etiology and pathogenesis of this disease are still unclear
$[1,3,6,9]$. In the literature on this issue, there are statements that endocrine factors play a well-known role in the pathogenesis of local vascular reactions that lead to the hydropsis of the labyrinth. In addition, it is known that 
the onset of the disease in women often coincides with periods of physiological or pathological decrease in the hormonal function of the ovaries: the hemorrhagic phase of the menstrual cycle, menstrual disorders accompanied by hypoestrogenia (amenorrhea, oligomenorrhea, a state after extirpation of the uterus, appendages, etc.). At the same time, there are no observations of Meniere's disease attacks during pregnancy and other physiological or pathological conditions of the generative sphere of the female body, accompanied by hypoestrogenia $[2,3,7,10,11]$. The main female sex hormones produced in women of childbearing age, mainly in the ovaries, are estrogens and progesterone. The latter is Central to the biosynthesis of steroids, estrogens, in particular corticosterone and aldosterone, i.e. hormones that play a leading role in regulating metabolic processes in the body (carbohydrate, water, electrolyte balance, calcium metabolism), as well as affecting the permeability of the walls of venules and capillaries by changing the polymerization of acidic mucopolysaccharides near the vascular connective tissue and affecting the state of the clotting system $[4,6,8,10]$.

In previous reports, the results of a biochemical study of women's sex steroids in Meniere's disease and the influence of the state of hormonal metabolism on the occurrence and development of vestibular disorders in this pathology were analyzed. At the same time, the majority of women (78\%) with Meniere's disease revealed a significant (2-3 times) decrease in the excretion of pregnandiol - a metabolite of progesterone and estrogens against the background of an attack of disorders and an increase in the excretion of these hormones to the norm during remission $[2,4,5]$. The excretion of androgens during the attack increased by 2-3 times compared to the control, and during remission was lower than normal. These data undoubtedly indicate a significant change in the balance of steroid hormones during an attack of Meniere's disease, which is a negative pathogenetic factor that contributes to the progression of the disease. Taking into account the above, we have developed a scheme of hormone therapy for attacks of vestibular disorders in Meniere's disease $[3,6,9,11]$. We selected a group of 18 women with Meniere's disease who applied to the clinic No. 1 of the Samarkand medical Institute in the ENT Department. Patients were treated in the period from 2015-2018 at the age of patients from 30 to 50 years. When studying the hormonal background, they were found to have characteristic changes in the excretion of sex steroids, the main disease was characterized by frequent attacks of dizziness, hearing loss in one or both ears, noise in the ear, a violation of static that occurred either in 1-3 days, or against the background of the hemorrhagic phase of the menstrual cycle. The diagnosis of the disease was established after a thorough clinical, audiological and vestibulometric examination. Audiological examination included tonal threshold, suprathreshold (Si-Si-test) and speech audiometry, determination of thresholds for perception of auditory sensitivity to ultrasound by B. M. Sagalovich, vestibulometric and electrostagmographic examination using rotational and caloric tests. A moderate degree of hearing loss at the main speech frequencies (500, 1000 and $2000 \mathrm{~Hz}$ ) up to 50 $\mathrm{dB}$ was found in 12 patients, more pronounced in 6. Normal thresholds of auditory sensitivity and lateralization of ultrasound in the worsehearing ear were registered in all 18 patients. According to the above-threshold tests, all patients had a pronounced phenomenon of accelerated loudness increase: the differential 
threshold for perception of sound power ranged from 0.2 to $0.4 \mathrm{~dB}$, and the SiSi test also reached $1000 \mathrm{~Hz}$.

Thus, on the basis of the results of the audiological examination, a lesion was found, which is regarded in the literature as a manifestation of intra-Labirint hydrops. During the vestibulometric study, all patients were found to have hypofunction of the vestibular analyzer, mainly on the side of the worsehearing ear. The duration of the disease ranged from 3 to 15 years. All women in this group had a normal 28-day menstrual cycle. During gynecological examination, there were no clinical manifestations of pathological changes in the system of generative organs. The dissociation between the normal menstrual cycle and the characteristic change in the excretion of sex steroids indicates that a decrease in the excretion of sex steroids is not an absolute indicator of a low content of them in the female body, but only indicates a change in their formation in the ovaries and a violation of metabolism. For this reason, clinically there may be no menstrual cycle disorders, which is noted in the women we examined.

During the period of electrostagmographic study, experimental vestibular normoreflexia is registered in patients with Meniere's disease between attacks. During remission, hyporeflexia was found on the affected side, as well as on the opposite side. But mostly, a characteristic feature is spontaneous nystagmus, which has a variable direction during the attack. But we must not forget about the diagnostic criteria for Meniere's disease, presented in table 1.

Table 1 Diagnostic criteria for Meniere's disease

\begin{tabular}{|l|l|}
\hline Possible & $\begin{array}{l}\text { There are attacks of vestibular dizziness, without impaired auditory } \\
\text { function } \\
\text { Sensorineural hearing loss combined with vestibular disorders }\end{array}$ \\
\hline Likely & $\begin{array}{l}\text { Single Dizziness } \\
\text { Audiometric impairment of auditory function } \\
\text { Tinnitus or feeling of fullness in the ear } \\
\text { Other causes of the disease excluded }\end{array}$ \\
\hline Significant & $\begin{array}{l}\text { Several episodes of dizziness lasting more than } 20 \text { minutes } \\
\text { Audiometric impairment of auditory function } \\
\text { Tinnitus or feeling of fullness in the ear } \\
\text { Other causes of the disease excluded }\end{array}$ \\
\hline
\end{tabular}

Unfortunately, the available methods of objective diagnostics of the inner ear condition do not allow detecting reliable signs of the disease, so the most common diagnostic criteria are those proposed by the American Academy of otorhinolaryngologists. Treatment of patients was carried out in remission for 2-3 menstrual cycles with continuous monitoring in the form of dynamic hormonal studies of sexual steroid excretion, gynecological, vestibulometric and audiological examinations. As medicinal drugs used infeksjon and microfollin Forte. Infekundin (1 tablet contains $2.5 \mathrm{mg}$ of norethinodrel and $0.1 \mathrm{~g}$ of methoxyethinyl estradiol) in gynecological practice is used as a means for the treatment of conditions, the Genesis of which is ovarian hypofunction, 
expressed in a decrease in the production of progesterone, therefore, the introduction of this drug to a certain extent compensates for the lack of estrogen and progesterone in the body. Microfollin Forte-a drug that compensates for the lack of estrogen in the body-is prescribed by gynecologists with a corresponding violation of the hormonal function of the ovaries. Contraindications to the use of infectin and microfollin Forte are malignant and benign neoplasms of the genitals and mammary glands, mastopathy, endometritis, a tendency to uterine bleeding, thrombosis. To exclude these diseases, patients were carefully examined clinically (blood test, coagulogram, fluorography, consultation with a gynecologist, therapist). Treatment was performed according to the following scheme: infecundin was prescribed 5 days before the beginning of the hemorrhagic phase of the cycle - 2 days for I tablet once a day, 3 days for 1 tablet twice a day, 2 days for I tablet once a day and 1 day for 0.5 tablets once a day, in the absence of a clinical effect during 2-3 menstrual cycles, patients were prescribed microfollin Forte $0.05 \mathrm{mg}$ twice a day after meals for 5 days. At the onset of clinical effect (cessation of attacks of vestibular disorders) in 3-5 months during one menstrual cycle, a course of fixing therapy was performed: starting from the 5 th menstrual cycle, patients received zundin 1 tablet per day for 20 days or microfollin Forte 1 tablet per day for 5 days before the start of the menstrual cycle for 7 days.

This treatment was performed under the control of a biochemical study of the excretion of sex steroids during 1-3 cycles of menstruation. The results of the study are presented in table 2.

Table 2. Excretion of sex steroids in women with Meniere's disease during hormone therapy.

\begin{tabular}{|c|c|c|c|c|c|c|}
\hline \multirow{2}{*}{$\begin{array}{l}\text { Statistical } \\
\text { analysis }\end{array}$} & \multicolumn{3}{|c|}{ Control group } & \multicolumn{3}{|c|}{ Before treatment } \\
\hline & $\begin{array}{l}\text { Estrogens } \\
\text { mg / day }\end{array}$ & $\begin{array}{l}\text { Progesteron } \\
\text { e mg / day }\end{array}$ & $\begin{array}{l}\text { 17-CS } \\
\mathrm{mg} / \text { day }\end{array}$ & $\begin{array}{l}\text { Estrogens } \\
\text { mg / day }\end{array}$ & $\begin{array}{l}\text { Progestero } \\
\text { ne mg / day }\end{array}$ & $\begin{array}{l}\text { 17-CS } \\
\mathrm{mg} / \text { day }\end{array}$ \\
\hline $\begin{array}{l}\mathrm{N} \pm \mathrm{m} \\
\mathrm{P}\end{array}$ & $\begin{array}{c}18 \\
21 \pm 1,3\end{array}$ & $\begin{array}{c}18 \\
0,86 \pm 0,05\end{array}$ & $\begin{array}{c}18 \\
18 \pm 1,5\end{array}$ & $\begin{array}{c}18 \\
9,2 \pm 0,7 \\
P<0,001\end{array}$ & $\begin{array}{c}18 \\
0,47 \pm 0,04 \\
P<0,001\end{array}$ & $\begin{array}{c}18 \\
20,0 \pm 1,2 \\
P<0,5\end{array}$ \\
\hline
\end{tabular}

\section{Note: 17-Cs-17-corticosteroids; $\mathrm{N}$ - number of studies}

The table shows that before treatment, the excretion of estrogens and progesterone was significantly reduced compared to that in the control group: oestrogen - up to $9.2 \pm 0.7$ $(\mathrm{P}<0.001)$, progesterone-up to $0.47 \pm 0.04$ $(P<0.001)$. The study of these hormones against the background of hormonal treatment showed a statistically significant increase in their content to the level in the control group: oestrogen to $21.0 \pm 1.3$
$(P<0.001)$, progesterone to $0.86 \pm 0.05$ $(P<0.001)$. During treatment, the study was performed on the 22-24 day of the menstrual cycle with a 28-day cycle and 1-2 months after the course of treatment. In the periods indicated after treatment, the excretion of oestrogen and progesterone decreased almost to the initial level.

Thus, the hormone therapy carried out was of a substitutive nature. Against the background of treatment, there was a relative 
normalization of the level of sex steroids. In this regard, vertigo attacks stopped in 6 patients, became weaker and less frequent in 8 patients, and the condition did not change in 4 women. It should be noted that a smaller effect was observed in women aged about 45 years, which is a period of extinction of the endocrine function of the genitals and a decrease in the body's ability to respond labile to the use of compensatory therapy with hormonal drugs. This can be judged by the fact that during treatment, the excretion of sex steroids in these patients did not differ on average from that in younger people, who had a good effect from hormone therapy. Based on the results of hormonal examination and treatment, it should be assumed that hormone therapy for women with Meniere's disease, which occurs against the background of ovarian hypofunction, is quite effective for relieving attacks of vestibular disorders. This therapy is of a substitutive nature. We can think that this is a relative normalization of water-salt metabolism in the body and as a result, a decrease in the hydropsis in the labyrinth. In combination with other medications, this therapy can be recommended for the treatment of Meniere's disease, since, in addition to filling the deficit of estrogens and progesterone in the body of a woman, it does not suppress the hormonal function of the endocrine glands. This is confirmed by the absence of withdrawal syndrome, as well as data from a biochemical study.

Authors ' participation: research concept and design, editing research concept and design, material collection, processing, writing- M.T. Nasretdinova

The authors declare that there is no conflict of interest.

\section{REFERENCES}

1. Насретдинова М. Т., Карабаев Х. Э. Совершенствование методов диагностики у пациентов с головокружением

//Оториноларингология Восточная Европа. - 2017. - Т. 7. - №. 2. - С. 194-198.

2. Насретдинова М. Т., Карабаев Х. Э. Головокружение в лор-практике //инновационные технологии в медицине детского возраста северокавказского федерального округа. 2017. - С. 216-219.

3. Насретдинова М. Т., Карабаев Х. Э. Оценка классических диагностических вестибулярных тестов у пациентовс кохлеовестибулярными нарушениями //Оториноларингология Восточная Европа. - 2017. - №. 3. - С. 323-329.

4. Nasretdinova M. T., Karabaev H. E., Sharafova I. A. Application of methodologies of diagnostics for patients with dizziness //CENTRAL ASIAN JOURNAL OF MEDICAL AND NATURAL SCIENCES. - 2020. - T. 1. - №. 1. - C. 29-33.

5. Nasretdinova M. T., Karabaev H. E. Vestibular neuronitis-the problem of systemic dizziness //European science review. - 2019. - T. 2. - №. 1-2.Singh R.K., Singh M. Otorhinolaryngology Clibics: An International Journal. 2012. Vol. 4(2). P. 81-85.

6. Joseph C. Segen, Concise Dictionary of Modern Medicine, New York, McGrawHill, 2006. ISBN 978-88-386-3917-3

7. Douglas M. Anderson; A. Elliot Michelle, Mosby's medical, nursing, \& Allied Health Dictionary sesta edizione, New York, Piccin, 2004. ISBN 88-299-1716-8

8. Singh R.K., Singh M. Otorhinolaryngology Clibics: An International Journal. 2012. Vol. 4(2). P. 81-85.

9. Wolschner U., Strösser W., Weiser, M., Klein P. Treating vertigo-combination 
Doi: https://doi.org/10.37547/TAJMSPR/Volumeo2Issue08-18

remedy therapeutically equivalent to dimenhydrinate: results of a referencecontrolled cohort study. Biol Med. 2010. Vol. 30. P. 184-190.

10. Lang T.A., Sesic M. (2011) as described statistics in medicine. An annotated guide for authors, editors and reviewers. Lane. with engl. Ed. V.p. Leonov. -M.: practical medicine, $-480 \mathrm{p}$.

11. Baloh R.W, Honrubia V. (2006) Clinical Neurophysiology of the Vestibular System. -New York: Oxford University Press, $-432 \mathrm{p}$ 